\title{
Poverty Eradication, Millennium Development Goals and Sustainable Development in Nigeria
}

\author{
Barnes Anger Ph.D \\ Department of Political Science, Benue State University, Makurdi, Nigeria \\ Tel: 234-080-3608-4474Ｅ-mail: Barnesanger68@yahoo.com
}

\begin{abstract}
The Millennium Development Goals (MDGs) are targeted at eradicating extreme hunger and poverty in the 189 member countries of the United Nations (UN). Nigeria as a member of the United Nation keyed into the implementation of the framework of the goals by formulating the National Economic Empowerment and Development Strategy (NEEDS), NEEDS as a policy is targeted at eradicating poverty and bringing about sustainable development. This is done through the establishment of Agencies like the National Poverty Eradication Programme (NAPEP). However, the scourge of poverty is till been felt by the majority of the citizens of the country who do not have access to primary health care, water and food. This paper analyses the effect of eradicating poverty in Nigeria via the instrumentality of the MDGs and concludes that government at various levels must come up with genuine poverty reduction programme if the challenges of poverty must be tackled.
\end{abstract}

Keywords: Poverty reduction/eradication, Sustainable development, Millennium development goals, Policy

\section{Introduction}

Poverty is not new but at each mention, it stirs a lot of misgiving. This is because it has a very devastating influence on its victims. It reduces the social and psychological prestige of its victims. Poverty is a condition of being poor. This could be evidenced even amidst plenty because there could be reeking poverty as a result of lack of knowledge to translate potentiality into practical creative benefits to actuate well being. In other words, if there is a poverty of something, it therefore means that there is a lack of it or the quality of it is extremely low.

The foregoing shows the picture of our beloved country, especially when a deep reflection is made on the Nigerian question and the Nigerian condition. It is so pathetic in the sense that the country that is potentially rich in oil and gas and other natural and agricultural resources can not boast of putting foods on the tables of its citizens. In fact, an average Nigerian is said to be living below one dollar. Research has it that the foundation of most social vices and corrupt practices both in high and low places is this scourge called poverty. At present, Nigerian is rated as one of the poorest country of the world; a country with abundant resources both in human and mineral replication.

It is as a result of this and others maladies that are experienced by the citizens of the world especially the Third World countries, that the United Nations in year 2000 in a meeting popularly referred to as Millennium Summit in the United States of America and arrived at the Millennium Development Goals (MDGs). According to UN, the 189 members of this organization, by 2015 are supposed to have met these goals. The nine goals have the 'eradication of extreme poverty and hunger' as the first goal to be met in the stipulated year.

As a member of the United Nations, Nigeria keyed into the MDGS and subsequently produced a policy document called the National Economic Empowerment and Development Strategy (NEEDS) to further see to the achievement of the millennium development goals. Specifically NEEDS has the following actionable goal:

- Wealth creation

- Employment generation

- Poverty reduction

- Value re-orientation

The NEEDS as a national policy was intended to meeting some of the goals of the MDGs, especially poverty reduction. In assessing the performance of MDGs and NEEDS in Nigeria, especially when it relates to 'poverty eradication' one can say without fear of contradiction that MDGs have performed below the expectations of Nigerians.

It is at the backdrop of this realization that this paper is set to examine the MDGs and poverty eradication as it is geared towards bringing sustainable development in Nigeria. First and foremost, there's need for some concepts to be clarified in order to facilitate our understanding

\section{Concepts Clarification}

\subsection{Poverty}

Poverty may be difficult to define. This is because many people see it in different perspectives. This connotes the fact that what may be termed poor may not be seen as poor by the other people. Onokerhoraye (2001) in Edoh (2003) states two issues that have been consistent in the attempt to define poverty. These are the questions of: 
(a) Who are the poor?

(b) At what level is poverty defined?

Conventional definitions in attempt to come to terms with these issues consistently conceive poverty as an economic issue. This is measured either as a minimum flow of real income per capita, or as a bundle of basic needs which may be qualified.

Social Scientists on the other hand recognize the need for broadening the definition of poverty. To this end, Kankwenda (2003.3) defines poverty as:

\section{A multidimensional phenomena influenced by a wide range of factors, these include poor people lack of access to income earning and productive activities and to essential social services.}

The Copenhagen Declaration of 1995 seems to shed more light on what really constitutes poverty when it assets:

Poverty has various manifestations, including lack of Income and productive resources sufficient to ensure sustainable livelihood; hunger and malnutrition, ill health; limited or lack of access to education and other basic services, increase morbidity and mortality from illness, homelessness and inadequate housing; unsafe environments, social discriminations and exclusion. It is also characterized by a lack of participation in decision and in civil, social and cultural life (Edoh 2003:68).

To Adejo (2006) poverty can be manifested in poverty of history, poverty of intellect and poverty of ideology. In any case the deprived are usually the poor. These are people of insufficient income, inadequate food intake, lack basic healthcare, lack shelter and safe drinking water, poor environmental cleanliness, lack access to basic education and skills, ignorant of fundamental human rights, and access to information. These however constituted the challenge and focus of the Millennium Development Goals (MDGs).

The MDGs came into existence in September 2000 at the United Nations Millennium Summit held in New York. It is aimed at reducing the number of people who lived on less than a dollar in year 2015 by pursuing the following eight objectives:

- Goals 1: Eradicate extreme poverty and hunger

- Goal 2: Achieve universal primary education

- Goals 3; Promote equality and empower women

- Goals 4; Reduce child mortality

- Goals 5; Improve maternal health

- Goals 6: Combat HIV/AIDs, Malaria and other diseases.

- Goal 7: Ensure environmental sustainability.

- Goal 8: Develop a global partnership for development (FRN, 2006).

Through the MDGs the world has unravelled the ugliness of global poverty and the basic tools with which it could be tackled as contained in the 8- point objectives. It has also provided additional entry point to engage governments on sustainable development issues. In addition, it has aroused local and international attention towards human centre development. Nigeria like other countries is optimistic that with the implementation of MDGs, poverty will be contained by 2015 .

The lesson from the foregoing is that poverty in Nigeria as indeed elsewhere must be defined in both manifest and consequential characteristics. It is against this background, that an examination of the incidence of poverty in the country shall be done in other segment of this paper.

\subsection{Development}

The world currently revolves around development as the need for development occupies a primary place in the lives of individuals and countries. This enhances the desire for people to move closer to development. Those who are farther from development wish they were closer and consistently strive to be closer to it while those who are close wish there is nothing separating them from it. In view of this, the concept of development turns out to be a vague term. This is due to the absence of an archetype of development, therefore changes considered to be development today may be considered primitive tomorrow. This accounts for the difficulty in articulating a definite concept of development in this ever-changing world. However some definitions by some scholars shall be highlighted in order to draw a connection between it and the subject matter of this paper.

Development according to Walter Rodney (1976) is the ability of the State to harness its natural resources or endowment for the well-being of the citizens.

But Sen (1989) views the concept as encompassing the economic, political, social, cultural and environmental dimensions. While economic and social progress and the elimination of poverty are the objectives of development, it includes also freedom from fear and arbitrary arrest; free speech, free association and the right to vote and be voted for. 
In his contribution to the meaning of development, Seers (1969) argues that, the questions to ask about a country's development are; what has been happening to poverty, unemployment and inequality? If all these have declined from high levels then beyond doubt this has been a period of development for the country concerned. If one or two of these central problems have been growing worse especially if all there have, it would be strange to call the result development even if per capita income doubled. This definition is centered on the improvement of the living condition of the citizens and it means that an economy could grow without developing.

It can be deduced from the preceding paragraphs that there is no universally accepted definition for development. It is inexplicably a normative term which at various times has meant economic growth, structural growth, autonomous industrialization, self-actualization as well as individual, national and cultural reliance.

\subsection{Sustainable Development}

Having looked at the concept of development, sustainable development simply put entails development that can be kept going or maintained. This should entail proper attention given to the transformation of productive forces and commensurate transformation in the social relations of production. The ability to maintain this guarantees sustainable development.

\section{The Nature and Incidence of Poverty in Nigeria}

Poverty is very real in Nigeria, over the last ten years; the quality of life of the average Nigerian citizen has progressively nose-dived. It is so endemic that people have started seeing it as part of their lot in life. In fact, scores of research studies have exposed the dimensions and the extent of poverty in Nigeria. For example Obadan and Odusola (2001), reveal how sharply the per capita income of Nigerians slipped from a high of over 1,280 dollars in 1980 to a low dollar in 1995 . This and other studies generally paint a grim picture of a nation trapped in a vortex of abject and abnormal poverty and declining productivity. Available statistics indicate how precarious life has become for the average Nigerian over the years in the face of suffocating levels of poverty.

The Nigerian situation becomes more pathetic when compared with other less endowed developing countries in Africa and other parts of the third world. Findings by Kayode and Odusola (2000), show, for example, that Nigeria's per capita income of $\$ 240$ in 1990 was well below the average of over $\$ 500$ for sub-Saharan Africa. The figure for Nigeria was well below those for Botswana (\$3210), Cote d' Ivoire $(\$ 6600)$, Egypt $(\$ 1,080)$, South Africa $(\$ 3,500)$, Mauritius $(\$ 3,710)$ (Obadan and Odusola (2008), In Edoh (2003:69), affirm that Nigeria is even rated in terms of percentage of population earning less than one dollar per day for randomly selected years.

The extent of poverty in the nation becomes even more alarming when a critical look is taken at the general income of the workers in the public service. The situation the Nigerian workers have found themselves in wage administration has necessitated most of the corrupt practices in the country's public service. The severity of poverty in Nigeria is equally glaring when other indicators of services and development are considered. The Vision 2010 Committee Report reveals that:

- $50 \%$ of Nigerians live below the poverty line.

- Only about $40 \%$ have access to safe drinking water;

- About $85 \%$ of the urban population lives in single houses with more than 7 occupants on the average.

- Only about $62 \%$ of Nigerians have access to primary health care.

- Most Nigerians take less than one-third of the minimum required protein and vitamins (Report 2010 Committee; Edoh 2003:71).

Poverty in Nigeria, a country with over 140 million people is all encompassing. The scourge has also shown a rising tendency in the past couple of decades accounting for the nations low development indicators and its ranking along side the poorest nations in the world (United Nations, 2001 and OXFAM, 2003). The majority of Nigeria's population lives in poverty with insufficient income to cover minimum standards of food, water, shelter, medical care and schooling. Given the Nation's rich endowment with natural resources, its poverty profile presents a sombre picture of a rich nation in decline (OXFAM, 2003). The table 1 below shows Nigeria's poverty indicators.

Table 1 above illustrates Nigeria's high poverty head-count ratio, measured at 70 and 91 percent of the population living on less than $\$ 1.00$ per person per day, and $\$ 2.00$ per person per day, respectively. It also reveals low levels of human capability with inadequate access to sanitation $(54 \%)$ and portable water $(62 \%)$ as well as low life expectancy at birth (52 years)

The analysis above shows clearly that Nigerians are indeed very poor whatever indices are used to identify or measure the phenomenon. This is a paradoxical situation in the sense that a country with rich natural and agricultural resources and good poverty reduction programmes such as Family Economic Advancement Programme and National Poverty Eradication Programme, have failed to improve the living standards of its citizens. 
The question is; why are Nigerians poor despite these laudable poverty reduction programmes and resources at the disposal of government? To summarily give the answer, Edoh (2003:71) identifies the following as some of the causes of poverty in Nigeria:

- Corruption and embezzlement

- Poor Leadership

- Lack of comprehensive National Poverty Alleviation

- Lack of sound agricultural policy and protracted neglect of the sector.

- Lack of basic infrastructures

- Rapid population growth

- Excessive internal and external debt burden.

The incidence of poverty in the country is so devastating, consequently the government like other 189 governments of the United Nations (UN) members embarked on poverty reduction programmes through the instrumentality of the Millennium Development soals. Next, is the critical examination of the 'wonders' of the MDGs in Nigeria.

\subsection{MDGs and Poverty Eradication: The Nigerian Experience.}

Just like other countries at the UN Millennium Summit that gave birth to the MDGs, Nigeria launched her own version of the MDGs poverty reduction or eradication programme. This and other programmes targeted at achieving MDGs are contained in the NEEDS document. In fact, NEEDS has 'poverty reduction' as its third actionable goal. To reduce poverty, NEEDS has set the following broad targets:

- Increase average per capita consumption by at least 2 per cent a year.

- $\quad$ Create about 7 million jobs by 2007.

- Increase immunization coverage to 60 per cent by 2007.

- Increase the percentage of the population with access to safe drinking water to at least 70 per cent by 2007 .

- Significantly increase school enrolment rates, especially for girls, and increase the adult literacy rate to at least 65 per cent by 2007.

- $\quad$ Significantly improve access to sanitation (NEEDS Document; 2004).

It is disheartening to discover that the Nigerian government did not meet these targets as contained in the policy document. Statistics reveal that Nigerians (especially the common man on the street) do not have access to safe drinking water, primary health care and the rate of unemployment is increasing on a daily basis. This paints an abnormal picture of the failure of NEEDS as a poverty reduction policy.

In line with the policy thrust of NEEDS, the government set up the National Poverty Eradication Programme (NAPEP) to tackle the challenges of poverty. But since the establishment of NAPEP, it has nothing tangible to show for its existence. NAPEP, an agency established by government to tackle poverty through empowerment, rather than focus on its mandate is today enmeshed in controversy. This led the Senate of the Federal Republic of Nigeria to move a motion to probe the activities of the agency since its creation (Guardian, Feb., 24, 2009).

The general impression is that NAPEP has failed the country because the poverty rate is still high. It is gathered that the agency has received a total of 11.8 billion Naira but it has northing to show for it (Guardian Feb., 24, 2009).

The local governments in collaboration with their State governments are not helping matters neither. There are reported cases of misappropriation and diversion of budgetary allocations that are meant to efficiently tackle some of the challenges of poverty in the country. The revelation from the Probe by the House Committee on Power and Steel into the National Integrated Power Project (NIPP) of the former President Obasanjo's administration buttresses the fact that intention on the pages of paper is not enough to tackle the scourge of poverty in this country. The probe revealed that over 10 billion US dollars was said to have been spent on the NIPP without any result to show for it (TELL Magazine, April 21, 2008).

By and large, the poverty reduction or alleviation programme of the government via the instrumentality of the MDGs and NEEDS has failed because of corruption and misappropriation of funds that are meant to carry out the programme. So MDGs have not successfully tackled the challenges of poverty in the country.

\section{An Overview of Sustainable Development Effort in Nigeria}

The centrality of poverty has made successive Nigerian governments to initiate sustainable development programmes aimed at alleviating or minimizing the deadly scourge of the poverty phenomenon. According to Odion (2009) programmes such as Operation Feed the Nation (OFN) which was launched in the 1970s and Green Revolution initiated in 1980 existed in the past to address the problems of poverty. Other efforts made by successive governments include the establishment of the Directorate of Food, Roads and Rural Infrastructure 
(DEFFRI), National Directorate of employment (NDE), Better Life Programme, (BLP), the Peoples' Bank of Nigeria (PBN), Family Support programme (FSP), Family Economic Advancement Programme (FEAP) and National Economic Empowerment and Development Strategy (NEEDs).

DFRRI was established in 1986 to construct feeder roads, provide rural water supply and rural electrification for the rural areas. The NDE was also established in 1986 to provide training, finance, and guidance for unemployed youths. BLP on the other hand came into being in 1987 to provide empowerment self-help and rural development programmes, skills acquisition and healthcare for the rural women.

The PBN was established in 1989 to encourage savings and credit facilities for the underprivileged in urban and rural areas while Community Banks were established in 1990 to operate banking facilities for rural residents and micro enterprises in urban areas. The FSP came on board in 1994 to provide healthcare delivery, child welfare, youth development, etc. FEAP and their state variants (SEAP) were initiated to provide credit facilities to support the establishment of cottage industries in rural areas.

The poverty Alleviation Progrmame (PAP) was an interim measure put in place in 2000 to address the problems of rising unemployment in the society and to increase the productiveness of the economy. It was designed to coordinate and monitor poverty alleviation effort and ensure that Nigerians were provided with steady sources of income, high purchasing power, quality education, water, healthcare and housing; stable and affordable power supply, among others.

In 2004, the Federal Government of Nigeria set up the NEEDs Strategy with a view to fighting the poverty scourge which it described as the most difficult challenge facing Nigeria and its people and the greatest obstacle to the pursuit of socio-economic growth.

Over the years attempts were made at alleviating poverty as reflected in the expression of commitment by successive governments, increase in the number of programmes and increasing commitment of resources in the process, however, very minimal success has been recorded or achieved. This, according to Muo (2007) is largely due to lack of coordination and commitment, lack of continuity, improper appreciation of the roots and magnitude of the problem, poor funding of the programmes, policy inconsistency, deficient infrastructural facilities and corruption. On the other hand, the Central Bank of Nigeria (2003) in its own view based on empirical investigation attributed the failure of poverty alleviation programmes to deterioration in fiscal discipline, corruption, political instability and inconsistent policies. To crown it all, NEEDs (2004) pointed out several factors that had hindered the effort of government at reducing the level of poverty. These included poor coordination; the absence of a comprehensive policy framework, excessive political interference; ineffective targeting of the poor leading to leakage of benefits to unintended beneficiaries; the unwidely scope of programme which caused resources to be thinly spread across too many projects design, implementation, monitoring and evaluation. The evidence suggests that the reforms and policies have not recorded the spectacular results expected. Thus, poverty alleviation remains a mirage in Nigeria.

\section{Eradication of Poverty within the MDGS Framework}

A major strategy for the implementation of MGDs in Nigeria as earlier noted is the NEEDs. The targets are to half by 2015 the proportion of people whose income is less than one dollar a day. The second target is half by 2015, the proportion of people who suffer from hunger (MDG, 2006).

Findings in 2004 indicated that poverty was more acute in rural areas in Nigeria and that some geo-political zones were particularly harder hit than others by the phenomenon while unemployment kept souring with the worst affected age bracket being 13-25 years (MDG, 2006). According to Muhammed, Nigeria's democratic experience has neither served the purpose of political emancipation nor led to economic betterment of the citizens. This is especially in the face of endemic poverty, hunger, unemployment and progressive disempowerment of a large chunk of the population. The prospect of escaping the life threatening situations and achieving sustainable growth and development is therefore linked to the MDGs. Again its actualization in Nigeria is still challenged by poor leadership, insincerity in governance, policy inconsistency, lack of adequate data base, high levels of corruption, etc. Some growth indices are often paraded by the Nigerian government, but, there is mismatch or disconnect between it and existing realities as the country still exhibit large symptoms of underdevelopment as reflected in the socio-economic lives of Nigerians. According to Odion (2009) $70 \%$ of the over 140 million Nigerians currently live below the poverty line of one dollar per day. The rapid urbanization, put at over 5 percent per annum, exerts severe pressure on ailing infrastructure. Nigeria is further ranked as one of the twenty five poorest nations in the world. This further intensifies youth unemployment.

The Human Development Report 2007/2008 on Nigeria showed that the Human development Index for Nigeria is 0.470 , which gives the country a rank of $158^{\text {th }}$ out of 177 countries. Life expectancy was 46.5 percent, ranking Nigeria as $165^{\text {th }}$ and adult literacy rate (\% ages 15 and older) was 69.1 , ranking Nigeria as $104^{\text {th }}$ out of 17.7 , the report also indicated the Human Poverty Index value of 37.3 percent for Nigeria, which ranked the country as $80^{\text {th }}$ among 108 developing countries for which the index were calculated (UNDP, 2008). According to Bello (2007) about one million Nigerian children were given out for forced and exploitative labour, of which 18 percent work in dangerous environments after school hours. Ten million Nigerian children of school age were 
reported to be out of school as shown by statistics on school enrolment released by UNICEF (2008). Eradicating poverty as step towards sustainable development in Nigeria via the MDGs framework continues to appear as a Herculean task.

\section{The Way forward for Nigeria}

Poverty in Nigeria is multi-faceted and deeply rooted. As such, an effective poverty reduction strategy in Nigeria must reflect its multidimensional nature, incorporating economic, social, cultural and political dimensions. Consequently, achieving the MDGs and hence unsustainable development through poverty reduction would require the decisive commitment of all stakeholders involved -individuals, communities, governments, non-governmental organizations and relevant international agencies.

First, the federal state and local government must ensure commitment in the areas of fund allocation for provision of social services that are beneficial to the poor; fostering efficient macro-economic and sectoral policies and the provision of an enabling environment to facilitate private sector economic framework.

Also, the government should recognize and encourage non-governmental organizations (NGOs) to be actively involved in a wide variety of activities to help provide development opportunities for grassroots communities considering the disproportionately high incidence of endemic poverty in the rural communities. Such encouragement of the NGOS should be closely accompanied by governments increased investment in human capital, a requirement necessary to equip the poor with education/training in order to enable them share in such grassroots opportunities.

Another strategy is for the government to realistically undertake a comprehensive study on the causes of poor implementation of development policies and strategies and develop a plan of action to address this critical and persistent problem.

There is also the need to develop long-term strategic plans that address unemployment, taking into consideration the educational curriculum and the needs of the labour market as well as strengthening the human and financial capacity of poverty alleviation institutions in the country.

Finally, there is the need to fully integrate the MGDs in the national development strategy and enhance monitoring thereof. There should be periodic and consistent reporting of the MDGs.

\section{Concluding Remarks}

Perhaps, no problem receives greater global attention today like poverty. In Nigeria poverty with its associated multiple deprivations appears to be the greatest degrader of the economy amongst other contemporary socio-economic problems. Interestingly, the incidence and severity of poverty in Nigeria are among the most challenging in the world, with serious economic and social consequences.

In course of this discourse, it was discovered that several regimes had initiated several policy responses in the past to address the poverty scourge in Nigeria. These policies and efforts failed to yield the desired results of alleviating poverty because they were only declarative without concerted effort and lacked the required political will among several other reasons.

Though the MDGs provide a platform for addressing the poverty issue once again, the situation from the Nigerian perspective indicates that there are still glaring constraints and challenges such as corruption, infrastructural inadequacies and others.

Energy for instance that is required by industries which should be used to drive the economy is still unreliable, undependable, epileptic and in some cases non- existent, the inability of the government to address effectively the power sector problems certainly have negative consequential effect on the economy and on poverty reduction. Therefore, for Nigeria to meet or advance greatly towards the MDGs in 2015, this essay aligns with the submissions of Igbuzor (2006) as espoused by Odion (2009) that there is need to formulate and implement policies that will promote transparency and accountability, overcome institutional constraints, promote pro-poor growth, bring about structural change, enhance distributive equity, engender social and cultural re-orientation, engineer political transformation, promote human development, generate employment and transform power relations.

\section{References}

Adejo, A.M. (2006). Poverty in the Land of Plenty. in NUBESS Journal of Contemporary Issues, Vol. 1, No.2.

Bello, A. M. (2007). the Activities of the Agency. Paper delivered at a Two day Capacity Building workshop on the Theme. Child Trafficking and Child Labour. Organized by Nigerian Agency for Prohibition of Trafficking in Persons and other Related matters (NSPTIP) Kano.

Central Bank of Nigeria. (2003). An Appraisal of Federal Government NAPEP. Bullion 27, January / March.

Edoh, T. (2003). Poverty and the Survival of Democracy in Nigeria in Nigerian Journal of Political and Administrative Studies. Vol. 1, No. 4.

Federal republic of Nigeria. (2006). Millennium development Goals (MDGs Information Kit. 
Igbuzor, O. (2006). The Millennium Development Goals; Can Nigerian meet the Goals in 2015? A Paper Presented at the Symposium on Millennium development Goals and Nigeria; Issues Challenges and Prospects, organized by the Institute of Chartered Accountants of Nigeria (ICAN) Abuja District, at Sheraton Hotels and Towers, July, 27.

Kankwanda, M. (2002). Poverty Eradication: Where Africa Stands. London: Economica.

Mahammed, A. A. (2006). Reflections on the Victory and crisis of Democracy in Saliu, H. A. Et al (eds) Democracy and Development. UNi Lorin.

Mno, I. (2007). Poverty: The Challenges, the Imperatives. Zenith Economic quarterly. 2 (12) September.

National Economic Empowerment and Development Strategy Document. (2004). National Planning Commission, Abuja.

Odion, W. E. (2009). Millennium Development Goals (MDGs) and the Poverty Questions in Nigeria. in Omotor, D. G and Akpotor, A. S. (eds) Millennium development Goals and Challenges Abraka: Delsu Investment Nigeria Ltd.

OXFAM. (2003). Measuring Poverty in Nigeria. Abuja.

Rodney, W. (1976). How Europe Underdeveloped Africa. Washington: Howard University Press.

Sen, A. (1989). Development and Freedom. New York: Anchor Books.

UNDP. (2001). Nigerian Human Development report (Millennium edition).

United Nations Development Programme (UNDP). (2008). Human Development Report 2007/2008 Country fact sheets Nigeria. [Online] available: http://hdrstats-undp.org/countires/countryfacsheets/ctyfsMGA.html(Retrieved August 19, 2008);

The GUARDIAN Newspaper, February 24, 2009.

The TELL Magazine, April 21, 2008.

www.un.org/millennium goals.

Table 1. Selected Poverty Indicators in Nigeria

\begin{tabular}{|l|l|}
\hline Variable & Value \\
\hline Population living on less than $\$ 1.00 /$ day & $70 \%$ \\
\hline Population living on less than \$2.00 day & $91 \%$ \\
\hline Poverty Gap \$1.00/day & $35 \%$ \\
\hline Poverty Gap \$2/day & $35 \%$ \\
\hline Access to improved sanitation & $59 \%$ \\
\hline Access to improved water source & $62 \%$ \\
\hline Life expectancy (both sexes) & 52 years \\
\hline
\end{tabular}

Source: World Resources Institute, 2004 